\title{
PEMBENTUKAN KARAKTER MELALUI LAYANAN BIMBINGAN DAN KONSELING ISLAMI
}

\author{
Ibnu Mahmudi *)
}

\begin{abstract}
Abstrak
Membentuk karakter menjadi bagian penting bagi bangsa kita ke depan. Pendidikan yang dilakukan sampai saat ini, hasilnya belum sesuai dengan yang diharapkan. Masih banyak terjadi berbagai peristiwa yang muncul dan memberikan pengaruh pada kehidupan peserta didik dalam hal perilaku yang menyimpang seperti penggunaan obat terlarang, pelecehan seksual, sikap agresif, tawuran, bullying, tawuran antar kerlompok remaja, perkelaian antara pelajar dan lain-lain.

Data dan fakta lain masih banyak perilaku korupsi yang justru di lakukan oleh para petinggi di negara dan berpendidikan tinggi.

Usaha untuk mengatasi hal tersebut perlu ada pembaharuan kurikulum dalam dunia pendidikan khususnya untuk pembentukan karakter, yang selama ini sudah ada melalui layanan bimbingan dan konseling di sekolah, namun hasilnya belum sesuai dengan harapan. Usaha lain yang diyakini dapat digunakan untuk membentuk karakter yang baik dapat dilakukan melalui perpaduan layanan bimbingan dan konseling dengan agama yaitu melalui layanan bimbingan dan konseling Islami.
\end{abstract}

Kata Kunci: Pembentukan Karakter, Layanan Bimbingan dan Konseling, Islam

* Ibnu Mahmudi adalah Dosen Program Studi Bimbingan dan Konseling Fakultas Ilmu Pendidikan IKIP PGRI Madiun. 


\section{Pendahuluan}

Pendidikan di negara kita sampai saat ini masih terus digoncang dengan berbagai fenomena yang tidak menyenangkan. Berbagai peristiwa yang muncul dan memberikan pengaruh pada kehidupan peserta didik dalam hal perilaku yang menyimpang seperti penggunaan obat terlarang, pelecehan seksual, sikap agresif, tawuran, bullying, tawuran antar kelompok remaja, perkelahian antara pelajar dengan sesama pelajar dan lain-lain. Perilaku ini merupakan manifestasi marah terhadap diri sendiri dan pihak lain dalam cara-cara destruktif seperti depresi, adiksi (narkoba, minum-minuman keras, judi); manifestasi fisik (masalah seksual: homo, gay; lesbian dan masalah kesehatan); degradasi moral/perilaku dan perilaku agresif (sindiran, saling mengolok-olok dan saling menjelekkan atau menjatuhkan orang lain). Pemberitaan di televisi-pun menyuguhkan tayangan tentang tindakan amoral siswa, seperti vandalism oleh siswa, pemerkosaan yang korban dan pelakunya siswa sekolah, pencurian, perampokan, geng motor yang berakhir dengan perkelahian dengan senjata tajam. Belum lagi kasus video porno yang ternyata 90\% pelaku dan pembuatnya adalah siswa remaja (Musfiroh, 2008) seperti yang diungkapkan oleh Mutia Hatta yang dilansir dalam Media Indonesia bahwa "Saat ini ada lebih dari 500 jenis video porno yang telah beredar, yang 90\% dibuat dan dilakukan oleh remaja Indonesia yang masih berstatus pelajar (Media Indonesia,10 April 2008). Kasus IPDN misalnya, diperkirakan sebesar 89,5\% praja IPDN mengalami kasus penyiksaan dan diantaranya terdapat 16 orang meninggal (Pikiran Rakyat, 2007). Fenomena lain yang melanda siswa remaja bahwa sekitar 6-20\% siswa SMA dan mahasiswa di Jakarta pernah melakukan hubungan seks pra-nikah. Selain itu hasil penelitian lain, menunjukan bahwa sebanyak 50\% dari pengunjung klinik aborsi berusia 15-20 tahun, dan 44,5\% dari pengunjung klinik aborsi berusia antara 15-20 tahun itu adalah hamil diluar nikah (Boyke, 1999).

Fenomena perilaku seks pra-nikah ini tidak hanya terjadi di Jakarta. Sebuah penelitian terhadap 37 remaja berusia 16-20 tahun di Jatinangor, Kabupaten Sumedang, Provinsi Jawa Barat pada tahun 1998, menunjukkan bahwa sekitar 80\% telah melakukan perilaku seksual necking; $70 \%$ pernah melakukan petting; 
dan 65\% pernah melakukan premarital intercourse (Nurhayati, 1998). Berdasarkan hasil penelitian Synovate Research tentang perilaku seksual remaja di 4 kota dengan 450 responden, yaitu: Jakarta, Bandung, Surabaya dan Medan. 44\% responden mengaku mereka sudah pernah punya pengalaman seks di usia 16 sampai 18 tahun. Sementara 16\% lainnya mengaku pengalaman seks itu sudah mereka dapat antara usia 13 sampai 15 tahun (www.situs.deskespro.info)

Kasus Narkoba di Indonesia berdasarkan laporan Badan Nasional Anti Narkoba, pada tahun 2007 ditemui sekitar 22.630 kasus. Di Jawa Barat sendiri, kasus narkoba masuk sebagai peringkat ke IV dengan 1.086 kasus (BNN, 2007).

Data dan fakta lain terkait dengan perilaku korupsi yang di lakukan oleh para petinggi di negatra kita (Sumber: Timothy Wibowo, Litbang Kompas) sebagai berikut:

1. 158 kepala daerah tersangkut korupsi sepanjang 2004-2011

2. 42 anggota DPR terseret korupsi pada kurun waktu 2008-2011

3. 30 anggota DPR periode 1999-2004 terlibat kasus suap pemilihan DGS BI

4. Kasus korupsi terjadi diberbagai lembaga seperti KPU,KY, KPPU, Ditjen Pajak, BI, dan BKPM

Informasi diatas menunjukan masih adanya korupsi yang dilakukan oleh petinggi negeri dan mereka yang berpendidikan tinggi oleh karena itu diperlukan adanya pembaharuan dalam pembentukan karakter bagi siswa di sekolah untuk dapat mencegah kenyataan tersebut terjadi masa yang akan datang.

Berdasarkan uraian tersebut di atas maka dunia pendidikan kita perlu ada upaya pembaharuan untuk meningkatkan kualitas pendidikan karena sampai saat ini dirasa masih ada berbagai kekurangan. Bukti adanya kekurangan tersebut sebagaimana kenyataan tersebut di atas. Salah satu usaha yang bisa dilakukan yaitu pembentukan karakter melalui layanan bimbingan dan konseling Islami.

\section{PEMBAHASAN}

1. Pembentukan Karakter.

a. Usaha Pendidikan dalam Membangun Karakter dan Budaya Bangsa. Perubahan-perubahan sosial yang cepat (rapid sosial changes), sebagai 
konsekuensi dari modernisasi, industrialisasi, kemajuan ilmu pengetahuan dan teknologi telah mempengaruhi nilai-nilai moral etika dan gaya hidup (value system and way of life). Tidak semua orang mampu menyesuaikan diri dengan perubahan-perubahan sosial tersebut, kadang-kadang dapat membuat individu jatuh sakit atau mengalami gangguan penyesuaian diri (adjustment disorder) (Corsini, 1981).

Perubahan-perubahan tata nilai kehidupan (psycho-social changes), antara lain dapat kita lihat pada:

1) Pola hidup masyarakat yang semula sosial-religius cenderung ke arah pola kehidupan masyarakat individual, materialistis dan sekuler;

2) Pola hidup yang semula sederhana dan produktif, cenderung ke arah pola hidup mewah, konsumtif, dan serba instan;

3) Struktur keluarga yang semula keluarga besar (extended family), cenderung ke arah keluarga inti (nuclear family), bahkan sampai pada keluarga tunggal (single parent family);

4) Hubungan kekeluargaan yang semula erat dan kuat, cenderung menjadi longgar dan rapuh (loose family relationship);

5) Nilai-nilai religius dan tradisional di dalam masyarakat, cenderung berubah menjadi masyarakat modern yang bercorak sekuler dan serba boleh serta toleransi berlebihan (permissive society);

6) Ambisi karier dan materi yang sebelumnya menganut azas-azas hukum dan moral serta etika, cenderung berpola tujuan menghalalkan segala cara, misalnya dengan melakukan KKN (Kolusi, Korupsi, dan Nepotisme).

Fenomena psikososial tersebut dengan segala keterkaitannya memunculkan berbagai macam permasalahan kehidupan dan pada sebagian orang dapat merupakan beban atau tekanan mental yang disebut sebagai stressor psikososial. 
b. Strategi Menciptakan Suasana Sekolah Yang Kondusif dalam Pembentukan Karakter

Keberhasilan menciptakan suasana sekolah yang kondusif untuk membiasakan dan membina pembentukan karakter akhlak mulia. Faktorfaktor dominan yang perlu ditumbuhkan kembangkan pembinaannya antara lain mengenai hal-hal berikut:

1) Keimanan

Keimanan sangat mempengaruhi perilaku seseorang. Keimanan ini perlu dibina dan ditumbuh-kembangkan sesuai dengan keyakinan agama masing-masing. Dengan keimanan diharapkan setiap peserta didik dapat membina dirinya menjadi manusia yang berbudi luhur. Melalui aktivitas sholat berjamaah dhuhur, shalat dhuha, hafalan Al-Qur'an, membiasakan mengucapkan salam.

2) Ketakwaan

Ketakwaan sebaiknya ditanamkan sejak dini kepada peserta didik sejak ia masuk sekolah melalui berbagai kegiatan, karena pada dasarnya kualitas manusia ditentukan oleh ketakwaannya. Ketakwaan merupakan cerminan dari nilai keimanan berupa perilaku yang terwujud dalam menjalankan perintah agama dan menjauhi larangannya.

3) Kejujuran Kemandirian dan Tanggung Jawab.

Berkorban demi kebenaran serta mengakui kesalahan, tindakan ini harus diwujudkan dan ditumbuh-kembangkan sehingga menjadi bagian dalam kehidupan. Dalam berbagai hal, sikap dan perilaku tidak berbohong, tidak curang, berani dan rela sehari-hari, baik yang berhubungan dengan Tuhan, diri sendiri maupun dengan orang lain. Kejujuran, kemandirian dan tanggung jawab harus menjadi sikap dan perilaku yang tegas harus dilaksanakan dalam kegiatan sehari-hari.

4) Keteladanan

Keteladanan merupakan salah satu kunci dalam upaya dan proses pendidikan karakter akhlak mulia. Kepala sekolah dapat memberi keteladanan kepada guru. Guru dapat memberikan keteladanan kepada 
para peserta didiknya, demikian pola kakak kelas kepada adik kelasnya. Keleteladanan jauh lebih penting dari pada memberikan pelajaran secara verbal, karena keteladanan adalah memberikan contoh melalui perbuatan atau tindakan nyata.

5) Suasana Demokratis

Suasana demokratis yang dimaksud adalah menghargai hak-hak orang lain dalam menyampaikan, pendapat, saran, ber-ekspresi, berkreasi. Susanan di sekolah haruslah suasana yang menunjukkan adanya kebebasan mengeluarkan pendapat, dan menghargai perbedaan pendapat sesuai dengan sopan santun berdemokrasi. Adanya suasana demokratis di lingkungan sekolah akan memberi pengaruh pada pengembangan karakter, terutama sikap saling menghargai dan saling memaafkan.

6) Kepedulian

Kepedulian terwujud antara lain dalam sikap empati dan saling menasehati, saling memberitahukan, saling mengingatkan, saling menyayangi dan saling melindungi sehingga setiap masalah dapat di atasi lebih cepat dan lebih mudah. Pembiasaan diri memiliki kepedulian di lingkungan sekolah perlu dimulai sejak dini.

7) Keterbukaan

Sistem manajenen sekolah harus bersifat transparan, artinya setiap kegiatan haruslah dilakukan secara terbuka, terutama yang berkenaan dengan masalah keuangan. Manajemen yang terbuka akan menghilangkan sikap saling curiga, berburuk sangka, dan menghilangkan fitnah, pagawai tata usaha, guru, dan oleh para peserta didik.

8) Kebersamaan

Kebersamaan adalah suasana tata hubungan antarwarga sekolah yang tercermin dari sikap dan perilaku seperti tolong menolong, tenggang rasa, saling menghormati, dan terbuka. Kebersamaan ini diarahkan untuk mempercepat hubungan silaturrohmi antara kepala sekolah, guru, peserta didik dan warga sekolah lainnya sehingga terwujud suatu suasana persaudaraan dalam tata hubungan sekolah yang harmonis. 
9) Keamanan

Keamanan di sini dimaksudkan sebagai rasa aman dan tenteram, bebas dari rasa takut, baik lahir maupun batin. Keamanan merupakan modal pokok untuk menciptakan suasana sekolah yang harmonis dan menyenangkan. Warga sekolah harus proaktif mengantisipasi dan mengatasi segala bentuk gangguan dari dalam dan luar lingkungan sekolah. Keamanan sekolah menjadi tanggung jawab warga sekolah, oleh karena itu yang pertama harus diciptakan ialah adanya suasana berbudi luhur dari setiap peserta didik. Dengan suasana yang demikian maka gangguan dari luarpun akan dapat diatasi dengan bijaksana.

10) Ketertiban

Ketertiban adalah suatu kondisi yang mencerminkan keharmonisan dan keteraturan dalam pergaulan antarwarga sekolah. Ketertiban antara lain harus tercermin dalam penggunaan waktu belajar mengajar, dan berhubungan dengan masyarakat sekitar. Ketertiban tidaklah tercipta dengan sendirinya melainkan harus diupayakan oleh setiap warga sekolah.

11) Kebersihan

Kebersihan adalah bagian dari iman. Suasana bersih, rapi dan menyegarkan akan memberi kesan menyenangkan bagi warga sekolah. Suasana yang demikian bukan hanya untuk waktu-waktu tertentu saja tetapi untuk seterusnya secara berkelanjutan. Kebersihan meliputi kebersihan fisik dan psikis, dan jasmaniah dan batiniah. Kebersihan batiniah ini sangat penting dibina antara lain ialah sikap jujur, ikhlas, jauh dari sifat dengki dan dendam.

12) Kesehatan

Kesehatan pun menyangkut aspek fisik dan psikis. Kesehatan fisik bagi warga sekolah hendaklah diupayakan dengan jalan berolah-raga secara teratur, makan makanan yang bergizi. Kesehatan psikis hendaklah dibangun dengan cara membangkitkan sikap seperti yang dikemukakan oleh WHO. 
13) Keindahan

Keindahan di sini dimaksudkan suasana lingkungan sekolah baik ruangan kantor, ruangan guru,, perpustakaan, dan ruang kelas yang mengesankan tertata rapi, maupun halaman sekolah, taman bunga dan lainnya menimbulkan kesan menyenangkan karena ada unsur estetikanya. Keindahan di lingkungan sekolah harus diciptakan oleh warga sekolah dan dijaga agar keindahan tersebut tidak sirna. Keindahan merupakan sebagian dari sifat manusia yang berbudi. Disamping keindahan ini, perlu juga diciptakan lingkungan sekolah yang rindang, ada pepohonan yang membuat lingkungan sekolah teduh, hijau dan sejuk. Suasana lingkungan yang rindang akan menciptakan iklim belajar mengajar yang lebih segar, tidak cepat melelahkan.

14) Sopan Santun

Sopan santun adalah sikap dan perilaku yang terkait dengan atau normanorma yang berlaku dalam masyarakat. Perilaku ini diwujudkan dalam hubungan dengan diri sendiri, keluarga, sekolah dan masyarakat.

2. Peran Layanan Bimbingan dan Konseling Islami dalam Membentuk Karakter

a. Layanan Bimbingan dan Konseling Islami.

Kedudukan dan hubungan antara bimbingan dan konseling terdapat banyak pandangan, salah satunya memandang konseling sebagai teknik bimbingan. Dengan kata lain, konseling berada di dalam bimbingan. Pendapat lain mengatakan bahwa bimbingan terutama memusatkan diri pada pencegahan munculnya masalah sementara konseling memusatkan diri pada pencegahan masalah yang dihadapi individu. Dalam pengertian lain, bimbingan sifat atau fungsinya preventif, sementara konseling kuratif atau korektif. Dengan demikian bimbingan dan konseling berhadapan dengan obyek garapan yang sama, yaitu problem atau masalah. Perbedaannya terletak pada titik berat perhatian dan perlakuan terhadap masalah tersebut. 
Masalah yang dihadapi atau digarap bimbingan merupakan masalah yang ringan, sementara yang digarap konseling yang relatif berat. Manakala masalah yang dihadapi individu (konseli) amat berat, konseling kerapkali harus menyerahkannya (me-"referal") kepada bimbingan ilmu lain, semisal psikoterapi, dengan kata lain konselor kliennya ke psikiater.

Oleh karena itu perlu pula ditegaskan bahwa masalah yang menjadi obyek garapan bimbingan dan konseling adalah masalah-masalah psikologis, bukan masalah-masalah fisik. Masalah fisik ini diserahkan kepada bidang yang relevan, misalnya kedokteran. Jadi, dalam kasus tertentu yang melibatkan fisik, terlebih dahulu ditangani fisiknya oleh kedokteran, baru kemudian masalah psikologisnya ditangani konselor.

Bimbingan tidak sama dengan pendidikan, walaupun pendidikan sering disebut juga sebagai bimbingan. Bimbingan merupakan bagian saja dari pendidikan. Pendidikan lebih luas cakupannya dibandingkan dengan bimbingan. Tentang hal ini akan diuraikan lebih jauh dalam pembahasan mengenai bimbingan dan konseling pendidikan Islami. Bimbingan sendiri didefinisikan orang bermacam-macam, ada yang sedemikian itu singkat rumusannya, ada pula yang amat panjang dengan merinci berbagai aspek yang terkandung dalam proses atau kegiatan bimbingan tersebut. Dalam tulisan ini bimbingan (Islami) ini secara singkat dirumuskan oleh beberapa ahli sebagai berikut:

Pengertian bimbingan dan konseling Islam menurut M Arifin (dalam Samsul Munir Amin, 2008) adalah "Kegiatan yang dilakukan oleh seseorang dalam rangka memberikan bantuan kepada orang lain yang mengalami kesulitan-kesulitan rohaniah dalam lingkungan hidupnya agar orang tersebut mampu mengatasinya sendiri karena timbul kesadaran atau penyerahan diri terhadap kekuasaan Tuhan Yang Maha Esa, sehingga timbul pada diri pribadinya suatu cahaya harapan kebahagian hidup saat sekarang dan dimasa yang akan datang”.

Anwar Sutoyo (2007) menyebutkan bahwa layanan bimbingan dan konseling Islami adalah "Upaya membantu individu belajar 
mengembangkan fitrah dan atau kembali kepada fitrah dengan cara memberdayakan (empowering) iman, akal, dan kemauan yang dikaruniakan oleh Allah kepadanya untuk mempelajari tuntunan Allah dan Rasulnya,agar fitrah yang ada pada individu berkembang dengan benar dan kokoh sesuai dengan tuntunan Allah SWT”.

Aunur Rahim Faqih (2001) berpendapat "Konseling Islami adalah proses pemberian bantuan kepada individu agar menyadari kembali eksistensinya sebagai makhluk Allah yang seharusnya dalam kehidupan keagamaannya senantiasa selaras dengan ketentuan dan petunjuk Allah, sehingga dapat mencapai kebahagiaan hidup di dunia dan akhirat".

Ahmad Muhammad Diponegoro (2011) menyatakan, Konseling Islami adalah layanan bantuan konselor kepada klien/konseli untuk menumbuh-kembangkan kemampuannya dalam memahami dan menyelesaikan masalah serta mengantisipasi masa depan dengan memilih alternatif tindakan terbaik demi mencapai kebahagiaan hidup dunia dan akhirat di bawah naungan rida dan kasih sayang Allah. Berikut membangun kesadarannya untuk menempatkan Allah sebagai Konselor Yang Maha Agung, dan sekaligus menggiring-nya untuk melakukan God counselling.

Bertolak dari pendapat diatas dapat ditarik pengertian bahwa bimbingan dan konseling Islam adalah suatu usaha pemberian bantuan kepada individu yang mengalami kesulitan rohaniah baik mental dan spiritual agar yang bersangkutan mampu mengatasinya dengan kemampuan yang ada pada dirinya sendiri melalui dorongan dari kekuatan iman dan ketakwaan kepada Allah SWT, atau dengan kata lain bimbingan dan konseling Islam ditujukan kepada seseorang yang mengalami kesulitan, baik kesulitan lahiriah maupun batiniah yang menyangkut kehidupannya di masa kini dan masa datang agar tercapai kemampuan untuk memahami dirinya, kemampuan untuk mengarahkan dan merealisasikan dirinya sesuai dengan potensi yang dimilikinya dengan tetap berpegang pada nilai-nilai Islam.

Dengan demikian bimbingan dan konseling Islami merupakan proses bimbingan sebagaimana kegiatan bimbingan lainnya, tetapi dalam seluruh 
seginya berlandaskan ajaran Islam, artinya berlandaskan Al-Qur'an dan Sunnah Rasul.

b. Asas Bimbingan dan Konseling Islami.

Asas-asas bimbingan dan konseling keagamaan islami pada dasarnya serupa dengan asas-asas pada bimbingan dan konseling di bidang lain. Namun demikian, di antaranya menurut Aunur Rahim Faqih (2001) patut disebutkan sebagai berikut:

1) Asas Fitrah

Fitrah merupakan titik tolak utama bimbingan dan konseling keagamaan islami, karena dalam "konsep" fitrah itu ketauhidan yang asli (bawaan sejak lahir sebagai anugerah Allah) terdapat. Artinya, manusia pada dasarnya telah membawa fitrah (naluri beragama Islam yang mengesakan Allah), sehingga bimbingan dan konseling islami harus senantiasa mengajak kembali manusia memahami dan menghayatinya.

2) Asas Kebahagiaan dunia dan akhirat

Jika manusia telah mampu memahami dan menghayati fitrahnya, maka itu harus terus dibina dan dikembangkan dalam rangka mencapai kebahagiaan dunia dan akhirat. Bimbingan dan konseling keagamaan islami membantu individu memahami dan menghayati tujuan hidup manusia yaitu mengabdi kepada Allah, dalam rangka mencapai tujuan akhir sebagai manusia, yaitu mencapai kebahagiaan dunia-akhirat tersebut.

3) Asas arnal saleh dan akhlaqul-karimah

Tujuan hidup manusia, kebahagiaan hidup di dunia dan akhirat itu, baru akan tercapai manakala manusia beramal 'saleh' dan beakhlak mulia, karena dengan perilaku semacam itulah fitrah manusia yang asli itu terwujudkan dalam realita kehidupan. Bimbingan dan konseling keagamaan islami membantu individu melakukan amal saleh dan berakhlak mulia sesuai dengan ajaran Islam. 
4) Asas "mauizatul-hasanah"

Bimbingan dan konseling keagamaan islami dilakukan dengan cara yang sebaik-baiknya dengan mempergunakan segala macam sumber pendukung secara efektif dan efisien, karena hanya dengan cara penyampaian "hikmah" yang baik sajalah maka "hikmah" itu bisa tertanam pada diri individu yang dibimbing.

5) Asas "mujadalatul-ahsan"

Bimbingan dan konseling keagamaan islami dilakukan dengan cara melakukan dialog antara pembimbing dan yang dibimbing, yang baik, yang manusiawi, dalam rangka membuka pikiran dan had piliak yang dibimbing akan ayat-ayat Allah, sehingga muncul pemahaman, penghayatan, keyakinan akan kebenaran dan kebaikan syariat Islam, dan mau menjalankannya.

c. Objek Bimbingan dan Konseling Islami

Objek (garapan) bimbingan dan konseling keagamaan islami menurut Aunur Rahim Faqih (2001) adalah hal-hal yang berkaitan dengan:

1) Upaya-upaya mencegah dan atau mengatasi problem yang berkaitan dengan ketidak-beragamaan;

2) Upaya-upaya mencegah dan atau mengatasi problem yang berkaitan dengan kesulitan memilih agama;

3) Upaya-upaya mencegah dan atau mengatasi problem yang berkaitan dengan kegoyahan iman (kekufuran);

4) Upaya-upaya mencegah dan atau mengatasi problem yang berkaitan dengan konflik pandangan/wawasan keagamaan;

5) Upaya-upaya mencegah dan atau mengatasi problem yang berkaitan dengan kekurangpahaman mengenai syariat Islam;

6) Upaya-upaya mencegah dan atau mengatasi problem yang berkaitan dengan ketidakmauan dan ketidakmampuan menjalankan syariat Islam dengan baik dan benar. 
d. Pembentukan Karakter Melalui Layanan Bimbingan dan Konseling Islami Sehubungan dengan pembangunan karakter dan budaya bangsa, pemeluk Islam tidak hanya cukup melihat sejumlah karakter bangsa yang tertulis dalam UUSPN, tetapi hendaknya menghayati dan mencontoh keteladanan yang ditunjukkan Nabi Muhammad Rosulullah Saw (Mahmud Al Misri, 2002:6-61), diantaranya:

1) ikhlas, 2) tepat janji, 3) perhatian, 4) yakin, 5) tawakal, 6) berbuat baik, 7) rendah hati, 8) berakhlak baik, 9) taqwa, 10) belas kasihan/empati, 11) pemberani, 12) takut kepada Allah, 13) adil, 14) penolong, 15) zuhud, 16) sabar, 17) keperwiraan, 18) kehati-hatian (wara), 19) penutup aib orang, 20) toleran, 21) menjaga lisan, 22) pemaaf, 23) memiliki rasa malu, 24) ridlo atau rela, 25) penyayang, 26) jujur, 27) amanat, 28) syukur, 29) berseri-seri wajahnya, 30) menjauhkan dari yang haram, 31) melapangkan kesempatan, 32) percaya atas kebesaran Allah, 33) mengharapkan keridhoan Allah, 34) lemah lembut, 35) ramah, 36) pemaaf dan pengampun, 37) penyimpan rahasia, 38) berlomba dalam kebaikan, 39) pemberi nasihat, 40) wasiat, dan 41) pembawa kabar baik.

\section{PENUTUP}

Berdasarkan temuan dan berbagai pendapat dan hasil penelitian para ahli diatas maka dapat disimpulkan bahwa:

Pendidikan karakter, sekarang ini mutlak diperlukan bukan hanya di sekolah saja, tapi dirumah dan di lingkungan sosial. Bahkan sekarang ini peserta pendidikan karakter bukan lagi anak usia dini hingga remaja, tetapi juga usia dewasa. Mutlak perlu untuk kelangsungan hidup Bangsa ini.

Bayangkan apa persaingan yang muncul ditahun 2021? Yang jelas itu akan menjadi beban kita dan orangtua masa kini. Saat itu, anak-anak masa kini akan menghadapi persaingan dengan rekan-rekannya dari berbagai belahan Negara di Dunia. Bahkan kita yang masih akan berkarya ditahun tersebut akan merasakan perasaan yang sama. Tuntutan kualitas sumber daya manusia pada tahun 2021 tentunya membutuhkan good character. 
Bagaimanapun juga, karakter adalah kunci keberhasilan individu. Dari sebuah penelitian di Amerika, 90 persen kasus pemecatan disebabkan oleh perilaku buruk seperti tidak bertanggung jawab, tidak jujur, dan hubungan interpersonal yang buruk. Selain itu, terdapat penelitian lain yang mengindikasikan bahwa 80 persen keberhasilan seseorang di masyarakat ditentukan oleh emotional quotient.

Bagaimana dengan bangsa kita? Bagaimana dengan penerus orang-orang yang sekarang sedang duduk dikursi penting pemerintahan negara ini dan yang duduk di kursi penting yang mengelola roda perekonomian negara ini? Apakah mereka sudah menunjukan kualitas karakter yang baik dan melegakan hati kita? Bisakah kita percaya, kelak tongkat estafet kita serahkan pada mereka, maka mereka mampu menjalankan dengan baik atau justru sebaliknya?

Sekolah sebagai lembaga pendidikan formal perlu adanya pembaharuan kurikulum yang berkaitan dengan pembentukan karakter.

Lembaga pendidikan sekolah perlu dikembangkan dengan penanaman kebiasaan yang baik agar menjadi karakter bagi para siswa di sekolah

Bentuk usaha yang perlu dikembangkan untuk pembentukan karakter di sekolah antara lain melalui layanan bimbingan dan konseling di sekolah

Salah satu usaha yang saat ini dipandang bisa untuk menanamkan karakter yang lebih baik dimasa yang akan datang adalah melalui layanan bimbingan dan konseling yang dipadukan dengan ajaran agama, yaitu melalui layanan bimbingan dan konseling Islami.

\section{DAFTAR PUSTAKA}

Al-Qur'anul Karim

Ahmad Muhammad Diponegoro, 2011. Konseling Islami. Panduan Menjadi Muslim Bahagia. Yogyakarta: Gala Ilmu Indonesia.

Anwar Sutoyo, 2009. Bimbingan dan Konseling Islami. Semarang: Widya Karya. Ainur Rohim Faqih, 2004. Bimbingan dan Konseling dalam Islam. Yogyakarta: UII Press.

Doni Kusuma, 2012. Pendidikan Karakter Utuh dan Menyeluruh. Yogyakarta: Penerbit Kanisius. 
Hamdan Bakran Adz-Dzaky, 2002. Konseling dan Psikoterapi Islam. Yogyakarta: Fahar Pustaka Baru.

Hanna Djumhana, 2003. Islam untuk Disiplin Psikologi. Jakarta: Departemen Agama Direktorat Jenderal Kelembagaan Agama Islam.

Pupuh Fathurrohman, AA Suryana, dan Fenny Fatriany, 2013. Pengembangan Pendidikan Karakter. Bandung: Aditama.

Retno Listyarti, 2012. Pendidikan Karakter dalam Metode Aktif, Inovatif, dan Kreatif. Jakarta: Penerbit Erlangga.

Samsul Munir Amin, 2010. Bimbingan dan Konseling Islam. Jakarta: Amzah.

Tohirin, 2011. Bimbingan dan Konseling di Sekolah dan Madrasah (Berbasis Integrasi) Jakarta: Rajawali Press.

Uman Suherman, A.S, 2011, Pidato Pengukuhan sebagai Guru Besar dalam Bidang Bimbingan dan Konseling pada Fakultas Ilmu Pendidikan UPI, Selasa, 15 November 2011

Undang-Undang Sistem Pendidikan Nasional tahun 2003. 